\title{
PERBUATAN PIDANA KESUSILAAN DALAM RANCANGAN UNDANG-UNDANG KUHP
}

\author{
Oleh: Sri Hartini \\ Jurusan PPKn FIS Universitas Negeti Yogyakarta
}

\section{Abstrak}

As an independent and sovereignty country, Indonesia sbould arrange KUHP (Kitap Undang-Undang Hukum Pidana) to avoid lost of criminalities that bave been increasing. The renewal of KUHP is very needed because it's not proper with the values of social politic, social philosopby, and social cultural of Indonesia people. It is the basic for sosial, criminal policy, and law enforcement. The urgency of revising of KUHP, specially putting susila crime put in draft criminal code (RUU KUHP) and almost the requirement still be formed widely, not distinguishing between criminal and people who break the rule, but the words "susila Crime", and the newly "statutory rape" and "incest".

According to the renewal, it's needed to direct it into the law development that is democratic and responsive, so that the law's function-that protect the society, can give fairness and as an development instrument will raise suitable with the principle of law country.

Although the draft criminal code (RUU KUHP) still need to be discussed again, remembering the effort to bave national KUHP is very urgent, so it's better that draft criminal code (RUU KUHP) is not need more time to be UU, in the other hand, technically we will face difficulties in law enforcement because the representatives and experts are more free to say their thoughts.

Kata Kunci: perbuatan pidana kesusilaan

\section{Pendahuluan}

Kitab Undang-Undang Hukum Pidana (KUHP) yang berlaku di Negara Indonesia hingga saat ini masih menggunakan KUHP peninggalan Pemerintah Hindia Belanda, yaitu "Weitboek van Strafrecht voor Nederland Indie" yang mulai berlaku sejak tahun 1915 dengan beberapa perubahan dan penambahan yang bersifat tambal sulam. Sebagai negara yang merdeka dan berdaulat tentunya berkepentingan untuk menyusun KUHP sendiri untuk memenuhi kebutuhan menangkal berbagai kejahatan yang kian hari meningkat, juga untuk disesuaikan dengan filosofi bangsa, serta ditulis dalam bahasa Indonesia. Selain hal tersebut, pada masa lalu apabila berfikir tentang alasan pembaharuan hukum pidana, maka yang dipikirkan adalah alasan politis (kebanggaan nasional untuk memiliki KUHP Nasional sendiri), alasan sosilogis (merupakan tuntutan sosial untuk mempunyai KUHP yang bersendikan sistem nilai nasional) dan alasan praktis (adanya KUHP 
yang asli berbahasa Indonesia). Namun dari kajian yang komprehensif terdapat pula alasan-alasan lain yang tidak kalah pentingnya, yaitu alasan adaptif yakni bahwa KUHP nasional di masa-masa mendatang harus dapat menyesuaikan diri dengan perkembangan-perkembangan baru, khususnya perkembangan internasional yang sudah disepakati oleh masyarakat beradap (Muladi, 1990: 3).

Dalam bidang hukum pidana, pembaharuan hukum pidana pada hakikatnya mengandung makna, suatu upaya untuk melakukan reorientasi dan reformasi hukum pidana yang sesuai dengan nilai-nilai sentral sosio politik, sosio filosofis dan sosio kultural masyarakat Indonesia yang melandasi kebijakan sosial, kebijakan kriminal dan kebijakan penegakan hukum Indonesia (Barda Nawawi Arief, 1996: 31).

Upaya pembaharuan KUHP telah dimulai lebih dari 25 tahun yang lalu, meskipun hingga saat ini upaya itu belum berhasil. Berhubungan dengan kriminalisasi pembaharun KUHP dimulai dari konsep yang diketuai oleh Basaroedin, pada tahun 1977 telah berhasil menyusun konsep Buku II tentang Kejahatan dan Buku III tentang Pelanggaran, yang akhirnya terkenal dengan "Konsep BAS". Konsep ini bersumber dari KUHP lama (WvS) dengan penyesuaian dan penambahan delik baru. Berikutnya pada tahun 1979 s.d. 1982 konsep BAS itu disempurnakan lagi oleh Tim yang diketuai oleh Prof. Oemar Seno Adji. Pada tahun 1982 s.d. 1986 dengan ketua Prof. Sudarto konsep sebelumnya diedit kembali yang menghasilkan konsep 1984/1985. Selanjutnya pada tahun 1986/1987 dengan ketua Prof. Roeslan Saleh, konsep ini diedit kembali menjadi konsep 1986/1987. Berikutnya dengan ketua Prof. Mardjono Reksodiputro, konsep periode yang lalu diedit kembali berturut-turut menjadi Konsep 1989/1990, Konsep 1991/1992 yang direvisi pada bulan Desember 1992 dan terakhir Konsep 1991/1992 s.d. revisi bulan Maret 1993. Selanjutnya diserahkan kepada Menteri Kehakiman kemudian dituangkan dalam Rancangan Undang-Undang tentang Kitab Undang-Undang Hukum Pidana tahun 1999-2000 yang sampai sekarang belum diproses di Dewan Perwakilan Rakyat.

Sehubungan dengan hal tersebut di atas penulis ingin mengkaji mengenai pembaharuan perbuatan pidana terhadap kesusilaan dalam Rancangan UndangUndang tentang KUHP. Di samping itu penulis ingin memberikan ulasan materi kejahatan terhadap kesusilaan sebagaimana dimuat dalam Rancangan UndangUndang KUHP (RUU KUHP). Ulasan ini tentu saja tidak dimaksudkan untuk mencampuri hasil kerja Tim yang telah bersusah payah meluangkan waktu dan mencurahkan segala daya pikiran untuk menyusun konsep akan tetapi sekedar memberikan sedikit bahan pemikiran yang barang kali berguna untuk kepentingan bersama, khususnya nanti dalam proses legislasi.

\section{Pengertian Perbuatan Pidana Kesusilaan (Delik Kesusilaan).}

Perbuatan pidana/delik kesusilaan adalah delik yang berhubungan dengan (masalah) kesusilaan. Definisi singkat, sederhana itu apabila dikaji lebih lanjut 
untuk mengetahui ruang lingkup delik kesusilaan ternyata tidak mudah, karena pengertian dan batas-batas "kesusilaan" itu cukup luas dan dapat berbeda-beda menurut pandangan dan nilai yang berlaku dalam masyarakat.

Sehubungan dengan hal tersebut dalam lokakarya mengenai Bab-Bab Kodifikasi Hukum Pidana Buku II yang diselenggarakan oleh BPEIN Departemen Kehakiman pada tanggal 23-25 April 1985 di jakarta, batas-batas atau ruang lingkup delik kesusilaan menurut Roeslan Saleh yang dikutif oleh Barda Nawawi Arief (1996: 291-293), mengemukakan bahwa :

“...pengertian kesusilaan hendaknya tidak dibatasi pada pengertian kesusilaan dalam bidang seksual, tetapi juga meliputi hal-hal lain yang termasuk dalam penguasaan norma-norma kepatutan bertingkah laku dalam pergaulan masyarakat. Oleh karena itu disarankan :

1. Untuk dimasukkan juga ke dalam bab mengenai "tindak pidana terhadap kesusilaan".
a. meninggalkan orang yang perlu ditolong.
b. penghinaan.
c. membuka rahasia.

2. Untuk dikeluarkan dari bab mengenai "tindak pidana kesusilaan"
a. menyalahgunakan alat-alat pencegah hamil di luar hubungan perkawinan yang sah.
b. kumpul kebo.
c. menjual/memberi minuman kepada orang lain yang sudah mabuk dan sebagainya.
d. menyerahkan anak di bawah 12 tahun untuk melakukan pengemisan dan sebagainya.
e. menyakiti hewan atau tidak memberi makan hewan miliknya atau peliharaannya."

Menurut Koespramono Irsan, kejahatan kesusilaan berupa: perkosaan, perzinahan, perbuatan cabul, pelacuran serta pelecehan seksual (Koesparmono Irsan dalam Suparman Mardzuki dkk, 1995: 85). Kemudian menurut Mudzakir kejahatan kesusilaan diartikan sebagai suatu bentuk pelanggaran/ kejahatan terhadap nilai susila (norma kesusilaan), sedang pelecehan seksual diartikan sebagai perbuatan yang memandang rendah atau menghinakan atau mengabaikan hak orang lain dalam bidang seksual. Jadi bisa dikatakan bahwa cakupan kejahatan kesusilaan sebenarbya meliputi kejahatan terhadap kesusilaan dan pelecehan sosial (Mudzakir dalam Suparman Mardzuki, 1995: 46). Berbeda dengan yang dikemukakan oleh Muladi bahwa pelecehan seksual tidak diatur dalam konsep KUHP baru (Muladi dalam Kedaulatan Rakyat, 27 Juli 1997: 8).

Dari beberapa pendapat tersebut di atas penulis sependapat dengan Barda Nawawi Arief, bahwa nilai-nilai kesusilaan itu bersumber pada nilai-nilai agama dan kesusilaan yang hidup di tengah-tengah masyarakat. Dengan demikian pelecehan seksual dapat dimasukkan dalam delik kesusilaan. Oleh karena 
itu perlu dipertimbangkan oleh para pembentuk RUU KUHP untuk dimasukkannya pelecehan seksual dalam perbuatan pidana/delik kesusilaan.

\section{Pembaharuan Perbuatan Pidana terhadap Kesusilaan dalam RUU KUHP}

Bab XV Buku Kedua Konsep Rangcangan KUHP Baru yang telah disempurnakan oleh Tim Kecil sampai dengan tanggal 17 Maret 1993 dengan titel "Tindak Pidana Terhadap Perbuatan Melanggar Kesusilaan di Muka Umum". Kemudian pada tahun 2000 RUU KUHP telah disempurnakan dengan titel " Tindak Pidana Terhadap Kesusilaan”. Titel yang digunakan dalam bab ini berbeda dengan titel yang dipergunakan pada KUHP lama (WvS). Perbedaannya, pada KUHP lama menggunakan titel "Kejahatan terhadap Kesusilaan". Sedangkan pada Konsep Rancangan KUHP Baru tidak menyebut dengan istilah kejahatan akan tetapi langsung menyebut dengan istilah "tindak pidana", yaitu "Tindak Pidana Kesusilaan. Penyebutan "kejahatan terhadap kesusilaan" pada KUHP lama sesuai dengan adanya pembedaan antara kejahatan yang materinya diatur dalam Buku Kedua dan pelanggaran yang materinya diatur dalam Buku Ketiga KUHP lama, sedang pada Rancangan Undang-Undang KUHP tidak diadakan pembedaan antara kejahatan dengan pelanggaran. Oleh karena itu dalam RUU KUHP semua delik langsung disebut dengan istilah "tindak pidana". Di samping perbedaan istilah titel yang digunakan juga berbeda jumlah pasal-pasalnya. Dalam KUHP lama kejahatan terhadap kesusilaan terdiri dari 22 pasal (Pasal 281 s.d. Pasal 303), tentang pelanggaran kesusilaan terdiri dari 15 pasal (Pasal 532 s.d. Pasal 547), sedang dalam RUU KUHP terdiri dari 30 pasal (Pasal 411 s.d. Pasal 441). Dari 30 pasal yang termuat dalam BAB XV, 20 pasal di antaranya mengambil pasal-pasal KUHP lama yang diperbaharui dan diperluas atau disempurnakan, 4 pasal dari Buku Ketiga KUHP lama dengan pembaharuan dan hanya 6 pasal yang materinya relatif baru. Adapun identifikasi materi tindak pidana kesusilaan yang bersumber pada RUU KUHP 1999/2000, sebagai berikut :

1. Yang termasuk melanggar kesusilaan sebagaimana diatur dalam Pasal 281 s.d. Pasal 283 KUHP lama, dalam RUU KUHP tidak hanya menyebutkan tulisan gambar atau benda tetapi juga "rekaman" (Pasal 412 ayat (1) huruf a). Hal ini menunjukkan adanya perluasan atau penambahan materi pelanggaran kesusilaan sebagaimana diatur dalam KUHP lama.

2. Mengenai perzinahan, Pasal 419 ayat (1) RUU KUHP ( Pasal 284 KUHP) disebut dengan istilah "permukahan". Rumusan tersebut pada dasarnya masih sama dan tetap merupakan delik aduan. Selain itu dalam RUU KUHP ditegaskan, bahwa yang dapat dipidana adalah:

a. Laki-laki yang berada dalam ikatan perkawinan yang melakukan persetubuhan bukan istrinya.

b. Perempuan yang berada dalam ikatan perkawinan melakukan persetubuhan dengan laki-laki yang bukan suaminya. 
c. Laki-laki yang tidak dalam ikatan perkawinan melakukan persetubuhan dengan perempuan, padahal diketahui perempuan tersebut berada dalam ikatan perkawinan.

d. Perempuan yan tidak dalam ikatan perkawinan melakukan persetubuhan dengan laki-laki, padahal diketahui bahwa laki-laki tersebut berada dalam ikatan perkawinan.

Di samping itu, dalam RUU KUHP tersebut delik zinah merupakan delik aduan. Ini dapat diketahui dari ketentuan Pasal 419 ayat (2) RUU KUHP, bahwa tindak pidana sebagaimana dimaksud dalam ayat (1) tidak dilakukan penuntutan kecuali atas pengaduan suami atau istri yang tercemar.

Menurut penulis apabila delik zinah kembali lagi menjadi delik aduan apakah tidak terlalu berorientasi pada nilai-nilai/budaya barat yang berbeda dengan nilai-nilai Pancasila. Oleh karena itu perumusan delik aduan pada tindak pidana perzinahan dalam Rancangan Undang-Undang KUHP perlu dipertimbangkan. Dan penulis sependapat dengan Barda Nawawi Arief, sekiranya memang ada alasan cukup kuat untuk melindungi pribadi/keluarga, memang patut dipertimbangkan untuk dijadikan delik aduan relatif, bukan sebagai delik aduan absolut. (Barda Nawawi Arief, 1996: 324).

3. Dapat dipidana perbuatan persetubuhan di luar perkawinan yang mengganggu perasaan kesusilaan masyarakat setempat (Pasal 420 ayat (1)). Di samping itu, juga mereka yang melakukan hidup bersama sebagai suami istri di luar perkawiran yang sah dan karena mengganggu perasaan kesusilaan masyarakat setempat (Pasal 422 ayat (1)). Hal ini tidak diatur dalam KUHP.

Berkaitan dengan persetubuhan di luar perkawinan yang dilakukan atas kemauan bersama tersebut, merupakan delik aduan oleh keluarga sampai derajat ketiga, atau oleh keapala adat, atau kepala desa/lurah setempat (Pasal 422 ayat (2)). Rumusan tersebut pada dasarnya masih sama dan tetap merupakan delik aduan seabagaimana diacantumkan dalam Rancangan KUHP Maret 1993, tetapi ada catatan: ada pendapat agar tidak merupakan delik aduan, antara lain untuk mencegah penyakit menular karena "ganti-ganti pasangan" (Mardjono Reksodiputro, 1995: 33).

4. Perbuatan yang dapat dipidana, adalah :

a. Laki-laki yang bersetubuh dengan seorang perempuan tidak bersuami dengan persetujuan perempuan tersebut karena janji akan dikawini, kemudian mengingkari atau karena tipu muslihat yang lain. (Pasal 421 ayat (1)).

b. Laki-laki yang tidak beristeri bersetubuh dengan persetujuan perempuan tersebut dengan perempuan tidak bersuami, yang mengakibatkan perempuan perempuan tersebut hamil dan tidak bersedia mengawini atau ada halangan untuk kawin yang diketahuinya menurut peraturan perundangundangan yang berlaku di bidang perkawinan (Pasal 421 ayat (2)). 
5. Tindak pidana sebagaimana telah diatur dalam Pasal 285 KUHP lama telah dirobah sehingga tidak lagi mensyaratkan adanya kekerasan dan dilakukan dengan wanita yang bukan istrinya.

Ditegaskan dalam Rancangan Undang-Undang KUHP, Pasal 423 ayat (1) yang termasuk tindak pidana perkosaan adalah :

a. Laki-laki melakukan persetubuhan dengan perempuan di luar perkawinan, bertentangan dengan kehendak perempuan tersebut.

b. Laki-laki melakukan persetubuhan dengan perempuan di luar perkawinan tanpa persetujuan perempuan tersebut.

c. Laki-laki yang melakukan persetubuhan dengan perempuan, dengan persetujuan perempuan tersebut, tetapi persetujuan tersebut dicapai melalui ancaman untuk dibunuh atau dilukai.

d. Laki-laki melakukan persetubuhan dengan perempuan, dengan persetujuan perempuan tersebut karena perempuan tersebut percaya bahwa ia adalah suaminya yang sah atau ia adalah orang yang seharusnya disetujuinya.

e. Laki-laki yang melakukan persetubuhan dengan seorang perempuan yang melakukan persetubuhan dengan seorang perempuan yang berusia di bawah 14 tahun, dengan persetujuannya.

f. Laki-laki yang melakukan persetubuhan dengan perempuan, padahal diketahui bahwa perempuan tersebut dalam keadaan pingsan atau tidak berdaya.

Berkaitan dengan persetubuhan yang' dilakukan bertentangan dengan perempuan sebagaimana dikemukakan, dapat dilihat dari adanya perlawanan dari pihak perempuan. Namun karena secara psikis maupun pisik keadaan perempuan terlalu lemah untuk melawan, maka persetubuhan yang dilakukan tanpa persetujuan perempuan tersebut juga dapat dipidana. Ketentuan tersebut tidak berlaku bagi laki-laki dan perempuan yang terikat dalam perkawinan, karena pada dasarnya dalam perkawinan tidak dapat terjadi perkosaan oleh suami tehadap istrinya atau yang dikenal dengan "marital rape". Perkosaan dalam perkawinan itu bertentangan dengan budaya bangsa Indonesia, karena dalam perkawinan suami istri mempunyai kewajiban yang sama, yaitu saling melindungi dan mengayomi. Di dalam Rancangan Undang-Undang KUHP telah diperkenalkan pula tindak pidana "statutory rape", yaitu dalam keadaan di mana wanita tersebut memberikan persetujuannya, namun wanita itu belum berumur 14 tahun.

Menurut penulis, rumusan tindak pidana perkosaan di dalam RUU KUHP tersebut selintas tampak bahwa ketentuan tersebut bertujuan untuk seluas mungkin dapat menjaring pelaku "tindak pidana perkosaan" dari kemungkinan lolos dati penuntutan dan pemidanaannya, sehingga tercapai tujuan hukum untuk melindungi hak asasi kaum perempuan yang selama ini dipandang kaum lemah dan tersisihkan dari perlakuan semena-mena dari pihak laki-laki. 
Di lain pihak, jika diamati secara teliti dan mendalam isi ketentuan Pasal 423 ayat (1) RUU KUHP tersebut mengandung makna dan dampak yang luas dalam sistem pembuktian yang akan diterapkan untuk mengungkap hasil tindak pidana perkosaan di dalam sidang pengadilan. Karena keterangan saksi korban sangat menentukan dalam pembuktian dan dari keterangan saksi korban tersebut yang harus dibuktikan oleh Jaksa penuntut umum, bahwa selama terjadinya perkosaan itu korban tidak menghendakinya, atau korban tidak menyetujuinya, atau korban menyetujuinya karena adanya ancaman, atau korban menyetujuinya karena pelaku adalah suaminya atau orang yang ia percayai, atau korban ternyata belum berusia 14 tahun. Belum lagi apabila korban perkosaan itu seorang perempuan yang memiliki latar belakang kehidupan pribadi atau reputasi buruk di dalam masyarakat. Jika tertuduh atau penasehat hukumnya minta "cross examination" atas saksi korban, apakah faktor latar belakang kehidupan ini dapat dijadikan pertimbangan dalam pembuktian. Dan apabila faktor latar belakang kehidupan ini tidak dapat dijadikan bukti yang mendukung bagi kepentingan pelaku, apakah proses penuntutan dan pembuktian atas pelaku tindak pidana perkosaan dapat dianggap merupakan proses peradilan yang jujur dan adil baik bagi kepentingan saksi korban maupun kepentingan pelakunya.

Menurut hemat penulis, dari berbagai persoalan yang akan dihadapi apabila mengacu Pasal 423 ayat (1) RUU KUHP yang akan datang sebagaimana telah diuraikan di atas justru apabila tidak sejak awal dipertimbangkan dengan hatihati akan merupakan kendala yang serius di dalam membuktikan kasus tindak pidana perkosaan yang akan datang.

6. Dalam Konsep RUU KUHP juga dirumuskan delik “incese” (Pasal 430 ayat (1), yaitu persetubuhan dengan anggota keluarga sedarah dalam garis lurus atau ke samping sampai derajat ketiga. Hal ini tidak terdapat atau diatur dalam KUHP.

7. Konsep RUU KUHP juga mengatur delik baru mengenai orang yang bergelandangan/berkeliaran di jalan tempat umum dengan tujuan melacurkan diri (Pasal 434).

Berhubungan dengan pembaharuan perbuatan pidana terhadap kesusilaan sebagaimana telah diuraiakan di atas, perlu kiranya arah pembaharuan pada pembangunan hukum yang demokratis atau hukum yang berkarakter responsif yang sesuai dengan prinsif negara hukum. Hal ini penting untuk ditegaskan karena berdasarkan ketentuan UUD 1945, Negara Indonesia adalah negara hukum (Perubahan Ketiga UUD 1945 Pasal 1 ayat (1)). Sesuai dengan karakter hukum yang responsif antara lain memiliki ciri-ciri bahwa tujuan hukum adalah memberi kewenangan (kompetensi) dan tujuan legitimasi bagi hukum yang responsif adalah memberikan keadilan yang substantif bukan keadilan prosedural (Nonet dan Selnick dalam Peters dan Koestini Siswosoebroto, 1990: 158). 
Dari kedua ciri tersebut nampak bahwa model hukum yang responsif hanya dapat berkembang dan dikembangkan dalam kondisi sosial politik tertentu yang kondosif bagi model hukum yang responsif. Ini berarti bahwa model hukum yang responsif tidak dapat berkembang dengan sendirinya, dalam arti hanya melalui tindakan-tindakan dan upaya di bidang hukum semata, akan tetapi diperlukan dukungan dari sistem politik yang lain seperti politik, budaya, ekonomi, dan sistem hukum itu sendiri.

\section{Penutup}

Berdasarkan uraian tersebut di atas, dapat dikemukakan bahwa pembaharuan perbuatan pidana terhadap kesusilaan dalam Rancangan Undang-Undang KUHP sebagian besar dari ketentuan perbuatan pidana terhadap kesusilaan yang diatur dalam KUHP lama masih dirumuskan dalam Rancangan Undang Undang KUHP dengan perluasan, penambahan atau penyempurnaan. Di samping itu dalam Konsep KUHP Baru tidak membedakan perbuatan pidana kejahatan dengan pelanggaran terhadap kesusilaan melainkan menggunakan istilah "Tindak Pidana Kesusilaan" dan yang berhubungan dengan tindak pidana terhadap kesusilaan diatur juga mengenai delik-delik baru yaitu, "statutory rape" dan "incest".

Berkaitan dengan pembaharuan perbuatan pidana kesusilaan dalam RUU KUHP tesebut, perlu kiranya arah pembaharuan pada pembangunan hukum yang demoktstis atau yang berkarakter responsif, sehingga fungsi hukum yang melindungi masyarakat, memberikan keadilan dan sebagai alat pembangunan akan tercapai sesuai dengan prinsip negara hukum.

Meskipun rumusan dalam Rancangan Undang Undang KUHP tentang kejahatan kesusilaan masih ada beberapa hal yang perlu memperoleh kajian ulang, akan tetapi mengingat usaha untuk memiliki KUHP Nasional itu sudah mendesak, maka sebaiknya Rancangan Undamg-undang KUHP itu jangan sampai diulur-ulur lagi untuk dijadikan UU. Sedangkan hal-hal yang bersifat teknis yang barangkali akan menimbulkan kesulitan dalam penegakan hukumnya, sebaiknya nanti dapat dipikirkan di DPR, karena justru di sanalah para wakil rakyat dan para pakar secara lebih leluasa akan dapat menyampaikan buah pikirannya. 


\section{Daftar Pustaka}

Arief, Barda Nawawi. 1996. Bunga Rampai Kebijakan Hukum Pidana, Citra Bandung: Aditya Bakti.

Direktorat Perundang-undangan Direktorat Jendral Hukum dan Perundangundangan Departemen Hukum dan Perundang-Undangan 1999-2000, Rancangan Undang-Undang Republik Indonesia Nomor .... Tabun .....Tentang Kitab Undang-Undang Hukum Pidana.

Irsan, Koesparmono. 1995. Kejabatan Kesusilaan dan Peleceban Seksusl Dalam Perspektif Kepolisia, Yogyakarta: Fakultas Hukum UII.

Reksodiputro, Mardjono. 1995. Pembaharuan Hukum Pidana. Jakarta: Pusat Pelayanan Keadilan dan Pengabdian Hukum (d/h Lembaga Kriminologi) Universitas Indonesia.

Mudzakir.1995. Kejahatan Kesusilaan dan Pelecehan Seksual Dalam Perspektif Politile Kriminal: Pelecehan Seksual Pergumulan Antara Tradisi Hukum dan Kekuasaan, Penyunting: Suparman Mardzuki d.k.k. Yogyakarta: Fakultas Hukum UII.

Muladi. 1990. Proyeksi Hukum Pidana Materiil Indonesia Di Masa Datang. Pidato Pengukuhan Diucapkan Pada Peresmian Penerimaan Guru Besar, Dalam Mata Pelajaran Ilmu Hukum Pidana pada Fakultas Hukum Universitas Diponegoro, Semarang, Tanggal 24 Februari 1990.

Peters dan Koesriani Siswosoebroto, 1990, Hukum dan Perkembangan Sosial. Buku teks Sosiologi Hukum. Buku III, Jakarta: Pustaka Sinar Harapan.

Kedaulatan Rakyat. 1997. "Memberantas Pelecehan Seksual Tetap Jadi Agenda Perjuangan Perempuan oleh Muladi," 27 Juli, hal: 8. 